\title{
Hematology and Plasma Chemistry as Indicators of Health and Ecological Status in Beluga Whales, Delphinapterus leucas
}

\author{
D.J. ST. AUBIN,${ }^{1}$ S. DEGUISE, ${ }^{2}$ P.R. RICHARD,${ }^{3}$ T.G. SMITH $^{4}$ and J.R. GERACI ${ }^{5}$
}

(Received 31 January 2000; accepted in revised form 10 August 2000)

\begin{abstract}
The capture of beluga whales, Delphinapterus leucas, for instrumentation or tagging afforded the opportunity to collect blood, which was analyzed to evaluate the animals' health and gain information on basic physiological systems. Here, we report on hematological and plasma chemical constituents in samples obtained from 183 belugas, 55 of which were handled during attempts to apply tracking instruments. The other 128 samples were either drawn from live belugas captured for exhibit in zoological parks or research or obtained from the fresh carcasses of whales taken by Inuit hunters. The data span a 15-year period beginning in 1983 and represent various beluga stocks in the Canadian Arctic. The majority of the specimens were collected during the summer or estuarine phase of the belugas' annual cycle. Comparisons by age group, sex, stock, season, and year revealed significant differences in most of the cellular and chemical constituents examined. These results demonstrate some of the variability that might be encountered when examining a "random" selection of belugas at a particular location and time. Immaturesized whales had higher leucocyte counts, electrolyte concentrations, enzyme activity, total protein, albumin, hemoglobin, and some metabolites than older animals. Sex alone was associated with few hematological and plasma chemical differences. Seasonal variation in thyroid hormone activity was linked to marked environmental changes associated with the transition from cold oceanic waters to relatively warm estuaries. Two belugas recaptured 19 and 24 days after instrumentation showed changes in leucocyte counts, hematocrit, and a variety of plasma chemical constituents, some of which indicate inflammation and a likely physiological response to handling and tagging stresses.
\end{abstract}

Key words: beluga, blood analysis, diagnostics, health, hematology, physiology, plasma chemistry, stress

RÉSUMÉ. On a profité du fait qu'on capturait des bélougas, Delphinapterus leucas, en vue de les équiper d'instruments ou de les marquer, pour prélever des échantillons de sang qu'on a ensuite analysés afin d'évaluer l'état de santé des individus et de collecter de l'information sur leurs grands systèmes physiologiques. Nous présentons ici un rapport sur les constituants hématologiques et chimiques du plasma dans des échantillons provenant de 183 bélougas, dont 55 ont été manipulés au cours de tentatives visant à les équiper d'instruments de poursuite. Les 128 autres échantillons ont été obtenus soit de bélougas vivants capturés en vue d'être placés dans des zoos ou pour la recherche, soit de carcasses fraîches de baleines prises par les chasseurs inuits. Les données couvrent une période de 15 ans, commençant en 1983, et représentent divers stocks de bélougas de l'océan Arctique canadien. La plupart des spécimens ont été recueillis durant l'été ou durant la phase estuarienne du cycle annuel du bélouga. Des comparaisons par groupe d'âge, sexe, stock, saison et année ont révélé des différences marquées dans la plupart des constituants cellulaires et chimiques examinés. Ces résultats font ressortir une certaine variabilité à laquelle on peut s'attendre quand on étudie un échantillon «aléatoire» de bélougas pris à un endroit et à un moment donnés. Par rapport à des individus plus âgés, les baleines qui n'avaient pas atteint leur taille adulte avaient un compte de globules blancs plus élevé, de même qu'une plus forte concentration d'électrolytes, une plus grande activité enzymatique, et un taux plus fort d'albumine, d'hémoglobine et de certains métabolites. Le sexe seul n'était associé qu'à quelques différences hématologiques et chimiques du plasma. Une variation saisonnière de l'activité des hormones thyrö̈diennes était liée à des changements nets du milieu correspondant à la transition des eaux froides océaniques aux estuaires relativement chauds. Deux bélougas recapturés 19 et 24 jours après avoir été équipés d'instruments montraient des changements dans le compte de globules blancs, dans l'hématocrite et dans divers constituants chimiques du plasma, dont certains révèlent une inflammation et probablement une réaction physiologique au stress dû à la manipulation et au marquage.

Mots clés: bélouga, analyse sanguine, diagnostic, santé, hématologie, physiologie, chimie du plasma, stress

Traduit pour la revue Arctic par Nésida Loyer.

\footnotetext{
${ }^{1}$ Mystic Aquarium, 55 Coogan Blvd., Mystic, Connecticut 06355, U.S.A.; dstaubin @ mysticaquarium.org

${ }^{2}$ Department of Pathobiology, University of Connecticut, 61 N. Eagleville Rd., Storrs, Connecticut 06269, U.S.A.

${ }^{3}$ Department of Fisheries and Oceans, Arctic Research Division, Freshwater Institute Science Lab, 501 University Crescent, Winnipeg, Manitoba R3T 2N6, Canada

${ }^{4}$ EMC Eco Marine Corp., Garthby, Quebec G0Y 1B0, Canada

${ }^{5}$ National Aquarium in Baltimore, 501 Pratt St., Baltimore, Maryland 21202, U.S.A.

(C) The Arctic Institute of North America
} 


\section{INTRODUCTION}

Blood analysis is a valuable tool routinely applied to assessing the health and physiological status of free-ranging animals (Beltran et al., 1991; Dunbar et al., 1997; Vogel et al., 1999; Borjesson et al., 2000). Few blood analysis studies have been performed on cetaceans, at least partly because of the logistical difficulties in obtaining samples from such mobile, wholly aquatic animals. Accidental or intentional entrapments in fisheries have afforded some opportunities to examine blood constituents in harbor porpoises, Phocoena phocoena (Nielsen and Andersen, 1982; Koopman et al., 1995, 1999), and longfinned pilot whales, Globicephala melaena (melas) (Medway and Moldovan, 1966), while directed efforts to capture and release bottlenose dolphins, Tursiops truncatus, have resulted in a robust data series for that species (Asper et al., 1990; St. Aubin et al., 1996). Apart from these efforts, much of what is known about the hematology and plasma chemistry of cetaceans is derived from monitoring of captive animals (Ridgway et al., 1970; MacNeill, 1975; Cornell, 1983; Cornell et al., 1988; Asper et al., 1990).

In recent years, the occurrence of mass mortalities (dieoffs) of cetaceans has prompted efforts to evaluate the health status of species such as bottlenose dolphins. In addition to ongoing monitoring of disease and tissue burdens of anthropogenic contaminants, programs involving the live capture and release of small odontocetes have been developed to establish health profiles of individuals randomly selected from the population (Hansen and Wells, 1995, 1996). Such data would provide baselines for comparison in the event of future changes in health or environmental conditions. Deviations from expected findings in blood and other indices might signal the onset of a population-wide decline in health or condition.

Beyond their utility as health indicators, blood constituents can provide insight into an organism's physiological adaptations or abilities. Erythrocyte parameters have been correlated with diving ability (Ridgway and Johnston, 1966; Ridgway et al., 1984; Hendrick and Duffield, 1991) and used to distinguish ecological variants of the same species (Duffield et al., 1983). Environmental conditions associated with seasonal changes in habitat can influence levels of circulating thyroid hormones in beluga whales, Delphinapterus leucas (St. Aubin and Geraci, 1989a). Stressful stimuli appear to elicit distinctive adrenocortical responses in cetaceans (St. Aubin and Geraci, 1990; St. Aubin et al., 1996) and phocid seals (St. Aubin and Geraci, 1986), possibly as a common adaptation to the marine environment. Levels of other plasma chemical constituents, such as urea nitrogen and electrolytes, are consistently different in cetaceans than in most terrestrial mammals. It is important, therefore, to establish expected values for individual species under defined conditions in order to interpret the findings of a health-monitoring program based on blood analysis (Borjesson et al., 2000).

Two studies have examined blood values in belugas, one based on long-term captive animals (Cornell et al.,
1988) and the other focusing on changes occurring during 10 weeks of acclimation following capture (St. Aubin and Geraci, 1989b). Both involved belugas from the western Hudson Bay stock, one of up to 16 geographically separate stocks in North American waters (IWC, 2000). Potential differences based on environmental factors, such as habitat or season, or biological parameters, such as age, sex, or lineage, could not be considered in these earlier studies. Given the marked seasonal changes that characterize the beluga's annual cycle and the potential for other biological influences on blood constituents, a more detailed investigation of these parameters was undertaken. The opportunity to pursue this work stemmed largely from the live capture of belugas, either for display or research, or to apply tracking instruments for ongoing studies of their movements and diving activity in various locations throughout the North American Arctic (Richard et al., 2001a, b). Here, we present the findings of blood analyses conducted over a 15-year period (1983-97) using samples from three stocks of belugas sampled at 11 locations in spring, summer, and fall. We examine the effects of age, sex, season, and stock on the various constituents. The data set includes the values published previously by St. Aubin and Geraci (1989b) to allow greater scope of analysis for interannual and regional differences.

\section{MATERIALS AND METHODS}

We sampled 151 whales live-captured at Seal River and Churchill in Hudson Bay, in the Mackenzie region of the Beaufort Sea, and at Creswell Bay, Cunningham Inlet, Elwin Bay (Somerset Island), and Croker Bay (Devon Island) in the High Arctic, using the techniques described by Orr et al. (2001). The duration of the approach and chase was typically less than $15 \mathrm{~min}$, with the most vigorous pursuit leading to capture lasting less than $5 \mathrm{~min}$. In addition, we sampled 32 whales that were shot for food by Inuit hunters at the Nastapoca River, Salluit, Kangiksujuak in Hudson Bay, and in West Greenland, typically after a chase of a duration similar to that for the live capture. Table 1 shows the whales handled at each site.

Once the animals were restrained, blood samples were drawn as the first priority to reduce variation as a result of time-dependent changes in blood constituents. Specimens were obtained variously from the caudal aorta, the paired caudal veins, or, rarely, from the tail flukes. Collection techniques included direct draw into heparin- or EDTAtreated Vacutainer tubes (Becton Dickinson, Franklin Lakes, New Jersey) or into plastic syringes followed by transfer to the Vacutainers. Samples were kept cool on ice packs during summer collections; during spring and fall studies, ambient temperatures were low enough to cool the specimens adequately.

Blood was processed for hematological analysis or storage as plasma at the earliest opportunity, in some instances within $1 \mathrm{~h}$, but it took up to $6 \mathrm{~h}$ where capture 
TABLE 1. Age-class and sex distribution of beluga whales sampled at each field location.

\begin{tabular}{|c|c|c|c|c|c|c|c|c|c|}
\hline \multirow[b]{2}{*}{ Stock } & \multirow[b]{2}{*}{ Location } & \multirow[b]{2}{*}{ Year } & \multirow[b]{2}{*}{ Season } & \multicolumn{2}{|c|}{ Female } & \multicolumn{2}{|c|}{ Male } & \multirow[b]{2}{*}{ Unclass. } & \multirow[b]{2}{*}{ Total } \\
\hline & & & & Mature & Immature & Mature & Immature & & \\
\hline \multirow[t]{12}{*}{ Hudson Bay ${ }^{1}$} & Seal River & 1985 & summer & 1 & 5 & 2 & 16 & - & 24 \\
\hline & Churchill & 1987 & summer & 2 & - & - & 13 & 3 & 18 \\
\hline & Churchill & 1988 & summer & 2 & 3 & - & 14 & 1 & 20 \\
\hline & Churchill & 1989 & summer & 1 & - & - & 5 & - & 6 \\
\hline & Churchill & 1990 & summer & 2 & 2 & 1 & 3 & - & 8 \\
\hline & Churchill & 1992 & summer & 2 & 2 & 1 & 5 & 1 & 11 \\
\hline & Churchill & 1993 & summer & 3 & 1 & 4 & 1 & - & 9 \\
\hline & Nastapoca & 1983 & summer & 1 & - & 3 & 1 & - & 5 \\
\hline & Nastapoca & 1984 & summer & 1 & 1 & 6 & 4 & - & 12 \\
\hline & Salluit/Kangiksujuak & 1985 & spring & 3 & - & 2 & 1 & - & 6 \\
\hline & Kangiksujuak & 1985 & fall & - & - & 2 & - & - & 2 \\
\hline & Kangirksujuak & 1986 & spring & 1 & - & 2 & - & - & 3 \\
\hline Beaufort & Mackenzie & 1995 & summer & 5 & - & 14 & - & - & 19 \\
\hline \multirow[t]{8}{*}{ High Arctic } & Creswell & 1994 & summer & 1 & - & 2 & - & - & 3 \\
\hline & Creswell & 1996 & summer & 1 & - & 3 & - & - & 4 \\
\hline & Cunningham & 1996 & summer & 3 & 1 & - & - & - & 4 \\
\hline & Cunningham & 1997 & summer & 3 & - & 3 & - & - & 6 \\
\hline & Elwin & 1996 & summer & 4 & - & 1 & - & - & 5 \\
\hline & Devon & 1995 & fall & 4 & - & 2 & - & - & 6 \\
\hline & Devon & 1996 & fall & 4 & - & 4 & - & - & 8 \\
\hline & W. Greenland & 1992 & spring & 1 & - & 3 & - & - & 4 \\
\hline \multicolumn{4}{|c|}{ Total (all locations) } & 45 & 15 & 55 & 63 & 5 & 183 \\
\hline
\end{tabular}

${ }^{1}$ For statistical groupings, no stock distinction was made between eastern and western Hudson Bay belugas, which were combined with those from Hudson Strait.

sites were some distance from the field camps. Plasma samples were frozen at $-20^{\circ} \mathrm{C}$ in conventional freezers or placed into liquid nitrogen transport containers. On delivery to the research laboratory, samples were typically transferred to $-60^{\circ} \mathrm{C}$ freezers and stored for varying periods up to 2 years prior to analysis using multi-channel autoanalyzers. Over the study period, a variety of instruments was used, reflecting equipment upgrades in the laboratories of the Pathology Department, Ontario Veterinary College, and the Laboratoire de Biochimie, Faculté de Médecine Vétérinaire, Université de Montréal, St. Hyacinthe, Quebec.

Manual hematological techniques were employed in the field for leucocyte, erythrocyte, and direct eosinophil counts using the Unopette system. Blood smears were prepared for later staining and differential counts of 200 cells per slide. Microhematocrit determinations were made using standard techniques. Samples collected in the Churchill and Seal Rivers in western Hudson Bay were taken within $12 \mathrm{~h}$ of collection to the clinical laboratory at the Churchill Health Center, where they were processed for hematology using automated particle counters. Instrumentation varied over the 9-year period (1985-93) during which studies were performed at this site.

Thyroid and adrenal hormones were analyzed by radioimmunoassay using commercially available kits (NCS diagnostics, Mississauga, Ontario, for reverse triiodothyronine (rT3); Intermedico, Willowdale, Ontario, for all others). All hormone test kits were validated for beluga specimens by dilution, spike-recovery of the target hormone, and, in the case of the thyroid hormones (TH), for the other principal TH. Specimens with total thyroxine (tT4) levels exceeding the highest standard supplied with the kit $(300 \mathrm{nmol} / \mathrm{L})$ were diluted $1: 2$ in $0.15 \mathrm{M}$ phosphatebuffered saline. For rT3, all samples were diluted 1:5 in phosphate buffered saline ( $0.15 \mathrm{M}, \mathrm{pH} 7.4)$. Assays for each hormone were performed as a single run, with an intra-assay coefficient of variation of less than $10 \%$.

Statistical analyses were performed using Statistix for Windows v. 2 (Analytical Software, Tallahassee, Florida). One-way ANOVAs were used to determine the influence of sex and age (immature, mature) within and between stocks (Beaufort Sea, Hudson Bay, and High Arctic). For statistical groupings, no stock distinction was made between eastern and western Hudson Bay belugas, which were combined with those sampled in Hudson Strait. Not all possible comparisons could be examined because of small or non-existent samples representing a particular age-class or sex. Of the 12 age, sex, and stock groups, five were represented by fewer than six individuals, and were not subjected to statistical comparisons. The remaining seven allowed nine potentially meaningful comparisons to be examined: the effect of age in males and females from Hudson Bay, the effect of sex in immature and mature whales from Hudson Bay and in mature whales from the High Arctic, and the effect of stock in mature males (3 pair-wise comparisons of the three stocks) and mature females (comparison of the High Arctic and Hudson Bay 
stocks). Beyond constraints imposed by the number of animals in each group, only 19 of the 55 blood indices could be statistically evaluated for all nine comparisons, since some cellular or chemical analyses were not performed in every case. A sample size of six was arbitrarily considered to be the minimum allowable for statistical comparison.

Season effects were examined for the High Arctic stock alone, considering only samples collected during the summer at various locations around Somerset Island and in the fall at Devon Island, and only for those constituents not displaying significant effects of either age or sex. Year-toyear variation was determined for seven summer seasons for the western Hudson Bay stock sampled at Churchill and Seal Rivers.

Age classes were established arbitrarily since it could not be ascertained in every case whether the whales had reached sexual maturity. Skin color provides some indication of age, at least to the extent that white animals can be considered mature. However, medium-gray females are sometimes seen with calves indicating that they may reach sexual maturity before they develop the white skin color. The whales were therefore categorized as immature- or mature-sized on the basis of stock-specific body length thresholds (Table 2; Doidge, 1990).

\section{RESULTS}

Table 3 summarizes the hematological and plasma chemical data derived from all belugas. Significant differences in some of those indices were attributable to age, gender, stock or season, as noted in Tables 4-8.

\section{Erythrocytes (Red Blood Cells, RBC)}

Within the Hudson Bay stock, the only gender-related difference apparent in any of the erythrocytic indices was that mean corpuscular volume (MCV) was greater in mature-sized females than in males (Table 5). Combining data from both sexes for the other erythrocyte values revealed significant differences in hemoglobin, mean corpuscular hemoglobin ( $\mathrm{MCH})$ and mean corpuscular hemoglobin concentration (MCHC) between age classes that were not apparent in the Hudson Bay animals alone (Table 4). Stock-associated differences were noted in mature males (Table 7) but not in mature females, though the only comparisons possible for the latter were for red blood cell count and hematocrit between Hudson Bay and Arctic stocks. Erythrocyte counts were significantly higher in mature male whales from the Beaufort Sea than in those from the High Arctic. Mature males from Hudson Bay showed higher levels of hemoglobin, $\mathrm{MCH}$, and MCHC than did those in the Beaufort Sea. A seasonal difference was apparent in mature whales of both sexes in the High Arctic, with significantly higher cell counts in fall than in summer (Table 8 ).
TABLE 2. Body-length criteria (cm) used to establish maturity categories for belugas sampled in three major geographical regions in the Canadian Arctic.

\begin{tabular}{lllc}
\hline \hline Area & Sex & Immature & Mature \\
\hline Hudson Bay & female & $251-300$ & $>300$ \\
& male & $251-325$ & $>325$ \\
Beaufort Sea & female & $251-325$ & $>325$ \\
& male & $251-350$ & $>350$ \\
High Arctic & female & $301-350$ & $>350$ \\
& male & $326-400$ & $>400$ \\
\hline \hline
\end{tabular}

In western Hudson Bay whales only, interannual variation was noted in erythrocyte counts, hemoglobin, hematocrit, MCV, and MCHC. Cell counts were significantly lower in $1990\left(3.25 \pm 0.35 \times 10^{12}\right.$ cells/ L $)$ than in $1985(3.66 \pm 0.30, p<0.05)$ or $1988(3.73 \pm 0.30, p<$ $0.001)$. Specimens from 1990 had significantly lower hemoglobin values $(206 \pm 15 \mathrm{~g} / \mathrm{L}, p<0.05)$ than specimens from either $1992(207 \pm 8)$ or $1988(230 \pm 13)$. Hematocrits in six animals sampled in $1989(0.62 \pm 0.03 \mathrm{~L} / \mathrm{L})$ were lower $(p<0.05)$ than in the seven in $1992(0.55 \pm 0.03)$. Significantly larger cells $(p<0.01)$ were noted in whales in 1989 (177 $\pm 5 \mathrm{fL})$ compared with either 1985 (160 \pm $12 \mathrm{fL})$ or $1988(158 \pm 15 \mathrm{fL})$. The pattern for MCHC was the inverse of that observed for MCV, with the highest MCHC observed in 1988 (389 $\pm 18 \mathrm{~g} / \mathrm{L})$, when derived cell volumes were significantly lower.

\section{Leucocytes (White Blood Cells, WBC)}

No significant age- or sex-related effects were noted in total leucocyte counts when analyzing data for the Hudson Bay and Arctic stocks. However, immature whales from all areas taken together had significantly higher WBC counts than did mature whales (Table 4); this pattern was evident in absolute counts of lymphocytes and segmented and band neutrophils.

Absolute counts of various leucocyte classes could be compared between the sexes only for immature whales from Hudson Bay, and the only difference was noted in monocyte counts (Table 5). Mature whales of both sexes showed stockrelated differences in total leucocyte counts, with Hudson Bay whales demonstrating uniformly higher counts than either of the other two stocks, though there were insufficient data from Beaufort Sea female belugas to allow comparisons with that group. Among the mature males, which represented all three stocks, Beaufort Sea whales had the lowest values. Small sample sizes precluded comparisons of leucocyte classes among the stocks for either sex.

Within the Hudson Bay group, significantly $(p<0.01)$ higher values were noted in $1990\left(14.7 \pm 5.0 \times 10^{9}\right.$ cells/L) than in $1985\left(9.6 \pm 2.2 \times 10^{9}\right.$ cells/L). Elevated total counts were observed sporadically within the sample, with three outliers $\left(>22.0 \times 10^{9}\right.$ cells/L) occurring in 1987,1990 , and 1993, all from immature animals from the Churchill River. Differences in neutrophil counts mirrored those for total 
TABLE 3. Summary of hematological and plasma chemical data obtained from beluga whales sampled in the Canadian Arctic over a 15year period beginning in 1983. All whales were at least two years of age.

\begin{tabular}{|c|c|c|c|c|c|}
\hline Parameter & Unit & $\mathrm{n}$ & Mean $\pm \mathrm{SD}$ & $95 \%$ Conf. Interval & Range \\
\hline \multicolumn{6}{|l|}{ Erythrocytes: } \\
\hline $\mathrm{RBC}$ & $10^{12} \mathrm{cells} / \mathrm{L}$ & 117 & $3.56 \pm 0.61$ & $3.45-3.67$ & $1.70-5.20$ \\
\hline Hemoglobin & $\mathrm{g} / \mathrm{L}$ & 101 & $216 \pm 18$ & $213-220$ & $165-260$ \\
\hline Hematocrit & $\mathrm{L} / \mathrm{L}$ & 119 & $0.59 \pm 0.04$ & $0.58-0.60$ & $0.485-0.675$ \\
\hline $\mathrm{MCV}$ & $\mathrm{fL}$ & 107 & $162 \pm 15$ & $159-164$ & $118-203$ \\
\hline $\mathrm{MCH}$ & pg & 100 & $60.0 \pm 7.6$ & $58.4-61.4$ & $34-86$ \\
\hline MCHC & $\mathrm{g} / \mathrm{L}$ & 102 & $367 \pm 32$ & $360-373$ & $229-448$ \\
\hline \multicolumn{6}{|l|}{ Leucocytes: } \\
\hline WBC & 109 cells/L & 124 & $9.9 \pm 4.7$ & $9.1-10.7$ & $1.8-25.7$ \\
\hline PMN & 109 cells/L & 64 & $3.7 \pm 1.4$ & $3.3-4.1$ & $0.9-7.8$ \\
\hline Band & 109 cells/L & 64 & $0.10 \pm 0.13$ & $0.05-0.13$ & $0-0.7$ \\
\hline Lymphocyte & 109 cells/L & 64 & $3.7 \pm 2.0$ & $3.2-4.2$ & $0.7-11.1$ \\
\hline Monocyte & 109 cells/L & 64 & $0.43 \pm 0.28$ & $0.37-0.50$ & $0-1.19$ \\
\hline Eosinophils & 109 cells/L & 64 & $2.6 \pm 1.6$ & $2.2-3.0$ & $0.9-10.2$ \\
\hline $\begin{array}{l}\text { Eosinophils } \\
\text { (direct count) }\end{array}$ & 109 cells/L & 76 & $2.7 \pm 1.3$ & $2.4-3.1$ & $0.9-6.8$ \\
\hline \multicolumn{6}{|l|}{ Electrolytes: } \\
\hline $\mathrm{Na}$ & $\mathrm{mmol} / \mathrm{L}$ & 145 & $163.3 \pm 8.1$ & $162-165$ & $134-189$ \\
\hline $\mathrm{K}$ & $\mathrm{mmol} / \mathrm{L}$ & 144 & $4.7 \pm 1.0$ & $4.5-4.8$ & $2.5-8.2$ \\
\hline $\mathrm{Na} / \mathrm{K}$ & & 144 & $36.3 \pm 7.1$ & $35.1-37.4$ & $20.2-62.3$ \\
\hline $\mathrm{Cl}$ & $\mathrm{mmol} / \mathrm{L}$ & 145 & $113.7 \pm 4.5$ & $112.9-114.4$ & $101-132$ \\
\hline Osmolality & $\mathrm{mOsmol} / \mathrm{kg}$ & 25 & $325.1 \pm 12.2$ & $320.1-330.1$ & $282-346$ \\
\hline Anion Gap & & 59 & $33.9 \pm 7.7$ & $31.9-35.9$ & $18.9-57.0$ \\
\hline $\mathrm{Ca}$ & $\mathrm{mmol} / \mathrm{L}$ & 145 & $2.66 \pm 0.32$ & $2.61-2.71$ & $1.03-3.54$ \\
\hline $\mathrm{P}$ & $\mathrm{mmol} / \mathrm{L}$ & 145 & $2.60 \pm 0.37$ & $2.54-2.67$ & $1.75-3.69$ \\
\hline $\mathrm{Fe}$ & $\mathrm{mmol} / \mathrm{L}$ & 104 & $88.4 \pm 52.1$ & $78.3-98.5$ & $0-265$ \\
\hline $\mathrm{Mg}$ & $\mathrm{mmol} / \mathrm{L}$ & 47 & $0.93 \pm 0.16$ & $0.88-0.97$ & $0.57-1.32$ \\
\hline $\mathrm{CO} 2$ & $\mathrm{mmol} / \mathrm{L}$ & 60 & $15.0 \pm 6.1$ & $13.5-16.6$ & $2.5-33.9$ \\
\hline \multicolumn{6}{|l|}{ Metabolites: } \\
\hline Glucose & $\mathrm{mmol} / \mathrm{L}$ & 145 & $6.2 \pm 1.1$ & $6.0-6.3$ & $4.1-9.5$ \\
\hline Urea & $\mathrm{mmol} / \mathrm{L}$ & 145 & $19.1 \pm 3.7$ & $18.5-19.7$ & $1.7-33.2$ \\
\hline Uric Acid & $\mathrm{mmol} / \mathrm{L}$ & 108 & $17.4 \pm 14.2$ & $14.7-20.1$ & $0-74$ \\
\hline Creatinine & $\mathrm{mmol} / \mathrm{L}$ & 122 & $257 \pm 66$ & $245-269$ & $123-501$ \\
\hline Total Bilirubin & $\mathrm{mmol} / \mathrm{L}$ & 57 & $4.9 \pm 4.0$ & $3.9-6.0$ & $0-14.6$ \\
\hline Free Bilirubin & $\mathrm{mmol} / \mathrm{L}$ & 48 & $2.4 \pm 2.3$ & $1.7-3.1$ & $0-7.6$ \\
\hline Conj. Bilirubin & $\mathrm{mmol} / \mathrm{L}$ & 48 & $1.4 \pm 1.5$ & $1.0-1.8$ & $0-6.2$ \\
\hline Cholesterol & $\mathrm{mmol} / \mathrm{L}$ & 136 & $4.7 \pm 1.6$ & $4.5-5.0$ & $1.3-9.8$ \\
\hline Triglyceride & $\mathrm{mmol} / \mathrm{L}$ & 105 & $1.78 \pm 0.75$ & $1.63-1.92$ & $0.51-5.03$ \\
\hline \multicolumn{6}{|l|}{ Enzymes: } \\
\hline $\mathrm{AP}$ & $\mathrm{IU} / \mathrm{L}$ & 138 & $189 \pm 133$ & $166-211$ & $25-818$ \\
\hline GGT & $\mathrm{IU} / \mathrm{L}$ & 117 & $16 \pm 10$ & $15-18$ & $0-62$ \\
\hline AlAT & $\mathrm{IU} / \mathrm{L}$ & 135 & $11 \pm 24$ & $7-15$ & $0-167$ \\
\hline AsAT & $\mathrm{IU} / \mathrm{L}$ & 106 & $77 \pm 35$ & $70-83$ & $5-231$ \\
\hline CPK & $\mathrm{IU} / \mathrm{L}$ & 144 & $162 \pm 80$ & $149-175$ & $45-499$ \\
\hline LDH & $\mathrm{IU} / \mathrm{L}$ & 92 & $236 \pm 98$ & $216-257$ & $18-574$ \\
\hline \multicolumn{6}{|l|}{ Protein: } \\
\hline Total protein & $g / L$ & 145 & $80.9 \pm 9.4$ & $79.3-82.5$ & $54-106$ \\
\hline Albumin & $\mathrm{g} / \mathrm{L}$ & 128 & $41.8 \pm 4.6$ & $41.0-42.6$ & $29-53$ \\
\hline Globulin & $\mathrm{g} / \mathrm{L}$ & 128 & $38.5 \pm 7.1$ & $37.3-39.8$ & $23-62$ \\
\hline AG Ratio & & 124 & $1.12 \pm 0.22$ & $1.08-1.16$ & $0.70-1.80$ \\
\hline Alpha 1 Globulin & $\mathrm{g} / \mathrm{L}$ & 68 & $3.65 \pm 1.66$ & $3.24-4.05$ & $1-8$ \\
\hline Alpha 2 Globulin & $\mathrm{g} / \mathrm{L}$ & 68 & $7.72 \pm 2.18$ & $7.19-8.24$ & $3-13$ \\
\hline Beta 1 Globulin & $\mathrm{g} / \mathrm{L}$ & 68 & $5.03 \pm 2.09$ & $4.52-5.53$ & $1-13$ \\
\hline Beta 2 Globulin & $\mathrm{g} / \mathrm{L}$ & 68 & $5.42 \pm 1.85$ & $4.98-5.87$ & $2-11$ \\
\hline Gamma Globulin & $\mathrm{g} / \mathrm{L}$ & 68 & $19.15 \pm 5.59$ & $17.79-20.50$ & $9-34$ \\
\hline \multicolumn{6}{|l|}{ Hormones: } \\
\hline $\mathrm{T} 4$ & $\mathrm{nmol} / \mathrm{L}$ & 141 & $185.3 \pm 66.9$ & $175.0-196.9$ & $42.5-381.0$ \\
\hline Free T4 & $\mathrm{pmol} / \mathrm{L}$ & 92 & $19.6 \pm 8.2$ & $17.9-21.2$ & $7.1-57.4$ \\
\hline T3 & $\mathrm{nmol} / \mathrm{L}$ & 144 & $2.33 \pm 0.83$ & $2.20-2.47$ & $0.34-5.11$ \\
\hline Free T3 & $\mathrm{pmol} / \mathrm{L}$ & 92 & $2.58 \pm 1.11$ & $2.35-2.81$ & $0.83-6.80$ \\
\hline rT3 & $\mathrm{nmol} / \mathrm{L}$ & 90 & $6.15 \pm 3.01$ & $5.52-6.78$ & $1.48-14.11$ \\
\hline Cortisol & $\mathrm{nmol} / \mathrm{L}$ & 115 & $89.1 \pm 45.5$ & $80.6-97.4$ & $15.5-204.4$ \\
\hline Aldosterone & $\mathrm{pmol} / \mathrm{L}$ & 98 & $325 \pm 613$ & $203-450$ & $0-3338$ \\
\hline
\end{tabular}

leucocytes. Neutrophils were elevated in Hudson Bay whales sampled in $1987\left(4.7 \pm 1.2 \times 10^{9}\right.$ cells $\left./ \mathrm{L}\right)$ compared to those sampled in $1985\left(3.6 \pm 1.1 \times 10^{9}\right.$ cells $\left./ \mathrm{L}\right)$. There were marked year-to-year variations in lymphocyte counts among animals captured in the Churchill and Seal Rivers, with means differing by a factor of more than two between 
TABLE 4. Age-related differences in plasma chemical constituents in beluga whales. Data from whales of both sexes were combined for this analysis only after excluding the possibility of gender-related differences in a homogeneous subset of the different age-classes. See Table 3 for unit of measure for each constituent.

\begin{tabular}{|c|c|c|c|c|c|c|c|c|}
\hline \multirow[b]{2}{*}{ Group } & \multirow[b]{2}{*}{ Constituent } & \multicolumn{3}{|c|}{ Immature } & \multicolumn{3}{|c|}{ Mature } & \multirow[b]{2}{*}{$p<$} \\
\hline & & $\mathrm{N}$ & Mean \pm SD & Range & $\mathrm{N}$ & Mean \pm SD & Range & \\
\hline \multirow[t]{19}{*}{ All data } & Hemoglobin & 61 & $223 \pm 16$ & $193-260$ & 36 & $204 \pm 16$ & $165-236$ & 0.001 \\
\hline & $\mathrm{MCH}$ & 60 & $62.1 \pm 5.4$ & $52-86$ & 36 & $55.6 \pm 9.1$ & $34-69$ & 0.001 \\
\hline & $\mathrm{MCHC}$ & 60 & $379 \pm 22$ & $339-448$ & 36 & $345 \pm 36$ & $229-389$ & 0.001 \\
\hline & WBC & 61 & $12.1 \pm 3.5$ & $6.5-24.3$ & 59 & $7.4 \pm 4.6$ & $1.8-25.7$ & 0.001 \\
\hline & PMN & 42 & $4.1 \pm 1.3$ & $2.4-7.8$ & 18 & $2.8 \pm 1.5$ & $0.9-6.2$ & 0.01 \\
\hline & Band & 42 & $0.11 \pm 0.14$ & $0-0.7$ & 18 & $0.03 \pm 0.04$ & $0-0.11$ & 0.05 \\
\hline & Lymphocyte & 42 & $4.0 \pm 1.5$ & $1.6-8.2$ & 18 & $2.7 \pm 2.5$ & $0.7-11.1$ & 0.05 \\
\hline & $\mathrm{Na}$ & 69 & $165.8 \pm 7.8$ & $134-189$ & 71 & $161.2 \pm 8.0$ & $135-182$ & 0.001 \\
\hline & $\mathrm{Ca}$ & 69 & $2.73 \pm 0.35$ & $1.86-3.54$ & 71 & $2.6 \pm 0.26$ & $1.03-3.08$ & 0.05 \\
\hline & Cholesterol & 67 & $4.1 \pm 1.4$ & $1.3-9.8$ & 64 & $5.4 \pm 1.5$ & $2.4-1.5$ & 0.001 \\
\hline & Triglyceride & 62 & $1.91 \pm 0.65$ & $0.58-3.69$ & 38 & $1.49 \pm 0.80$ & $0.51-5.03$ & 0.001 \\
\hline & $\mathrm{AP}$ & 62 & $238 \pm 138$ & $63-818$ & 71 & $134 \pm 93$ & $25-428$ & 0.001 \\
\hline & GGT & 47 & $11 \pm 7$ & $0-31$ & 68 & $20 \pm 10$ & $0-62$ & 0.001 \\
\hline & AlAT & 59 & $16 \pm 34$ & $0-167$ & 71 & $6 \pm 6$ & $0-38$ & 0.05 \\
\hline & $\mathrm{CPK}$ & 68 & $201 \pm 76$ & $81-499$ & 71 & $124 \pm 62$ & $45-402$ & 0.001 \\
\hline & LDH & 51 & $253 \pm 101$ & $18-574$ & 36 & $199 \pm 61$ & $98-366$ & 0.01 \\
\hline & Protein & 69 & $85.4 \pm 8.1$ & $64-106$ & 71 & $76.8 \pm 8.8$ & $54-97$ & 0.001 \\
\hline & Albumin & 57 & $44.4 \pm 4.0$ & $35-53$ & 69 & $39.7 \pm 3.9$ & $29-49$ & 0.001 \\
\hline & Globulin & 57 & $41.0 \pm 7.4$ & $27-62$ & 69 & $36.6 \pm 6.4$ & $23-57$ & 0.001 \\
\hline \multirow[t]{4}{*}{ Hudson Bay female } & CPK & 13 & $188 \pm 102$ & $102-499$ & 13 & $117 \pm 59$ & $65-271$ & 0.05 \\
\hline & $\mathrm{Fe}$ & 10 & $74.4 \pm 39.4$ & $28-136$ & 10 & $124.8 \pm 42$ & $45-193$ & 0.05 \\
\hline & Albumin & 13 & $45.0 \pm 3.8$ & $39-53$ & 11 & $41.6 \pm 2.7$ & $38-47$ & 0.05 \\
\hline & $\mathrm{T} 4^{1}$ & 13 & $245.8 \pm 66.9$ & $139-381$ & 12 & $150.6 \pm 41.2$ & $90-223$ & 0.001 \\
\hline \multirow[t]{2}{*}{ Hudson Bay male } & CPK & 54 & $205 \pm 70$ & $81-376$ & 8 & $92 \pm 24$ & $55-133$ & 0.05 \\
\hline & $\mathrm{T} 3^{1}$ & 61 & $2.80 \pm 0.75$ & $1.51-5.11$ & 13 & $1.98 \pm 0.54$ & $0.91-2.69$ & 0.001 \\
\hline
\end{tabular}

${ }^{1}$ Data for summer only.

TABLE 5. Sex-related differences in hematological and plasma chemical constituents in beluga whales. Data from whales of all age classes were combined only after excluding the possibility of age-related differences in a homogeneous subset of the gender groups. See Table 3 for unit of measure for each constituent.

\begin{tabular}{|c|c|c|c|c|c|c|c|c|}
\hline \multirow[b]{2}{*}{ Group } & \multirow[b]{2}{*}{ Constituent } & \multicolumn{3}{|c|}{ Female } & \multicolumn{3}{|c|}{ Male } & \multirow[b]{2}{*}{$p<$} \\
\hline & & $\mathrm{N}$ & Mean \pm SD & Range & $\mathrm{N}$ & Mean \pm SD & Range & \\
\hline All data & $\mathrm{RBC}$ & 37 & $3.37 \pm 0.68$ & $1.90-5.20$ & 77 & $3.66 \pm 0.55$ & $1.70-5.20$ & 0.05 \\
\hline \multirow{3}{*}{ Hudson Bay immature } & monocytes & 9 & $0.25 \pm 0.26$ & $0-0.70$ & 33 & $0.47 \pm 0.27$ & $0-1.19$ & 0.05 \\
\hline & aldosterone & 11 & $139 \pm 137$ & $0-419$ & 50 & $53 \pm 71$ & $0-441$ & 0.01 \\
\hline & $\mathrm{T} 4^{1}$ & 13 & $245.8 \pm 66.9$ & $139-381$ & 61 & $206.3 \pm 53.0$ & $62-344$ & 0.05 \\
\hline \multirow[t]{5}{*}{ Hudson Bay mature } & $\mathrm{MCV}$ & 12 & $173.0 \pm 7.6$ & $160-184$ & 8 & $166.8 \pm 3.4$ & $162-173$ & 0.05 \\
\hline & $\mathrm{K}$ & 12 & $4.7 \pm 0.7$ & $3.2-5.7$ & 8 & $5.4 \pm 0.8$ & $4.5-6.6$ & 0.05 \\
\hline & $\mathrm{NaK}$ ratio & 12 & $36.2 \pm 6.1$ & $30.0-51.9$ & 8 & $31.0 \pm 3.27$ & $26.3-35.1$ & 0.05 \\
\hline & GGT & 16 & $14 \pm 9$ & $0-29$ & 7 & $28 \pm 18$ & $10-62$ & 0.05 \\
\hline & $\mathrm{T} 4^{1}$ & 12 & $150.6 \pm 41.2$ & $90-223$ & 13 & $234.2 \pm 64.4$ & $14-360$ & 0.001 \\
\hline Arctic mature & urea & 20 & $16.8 \pm 2.8$ & $12.1-21.9$ & 13 & $18.7 \pm 2.2$ & $14.9-22.3$ & 0.05 \\
\hline
\end{tabular}

${ }^{1}$ Data for summer only.

the lowest $\left(3.1 \pm 1.1 \times 10^{9}\right.$ cells/ $\mathrm{L}$ in 1985$)$ and highest $(6.7$ $\pm 2.0 \times 10^{9}$ cells/L in 1988$)$ counts. Monocytes were not observed in the four samples collected in 1988, in contrast to the 1985,1987 , and 1990 specimens, in which averages of 0.45 to $0.57 \times 10^{9}$ cells $/ \mathrm{L}$ were noted.

\section{Electrolytes}

Age-related differences in Fe were found in females from Hudson Bay (Table 4); there were too few mature-sized males tested for comparison with younger males. Immature whales from all areas had significantly higher levels of $\mathrm{Ca}$ than adult animals (Table 4). Mature females from Hudson Bay had lower $\mathrm{K}$ levels, and consequently a higher $\mathrm{Na}: \mathrm{K}$ ratio, than did older males from that stock (Table 5).

Comparisons among stocks revealed significant differences in most electrolytes and elements, except $\mathrm{Cl}$ and $\mathrm{P}$ (Tables 6 and 7). Levels of $\mathrm{Fe}$ in mature females from Hudson Bay were significantly higher than those from the Arctic, but mature males from the same two stocks showed 
TABLE 6. Stock-related differences in hematological and plasma chemical constituents among mature-sized female belugas. See Table 3 for unit of measure for each constituent.

\begin{tabular}{|c|c|c|c|c|c|c|c|}
\hline \multirow[b]{2}{*}{ Constituent } & \multicolumn{3}{|c|}{ Stock - Arctic } & \multicolumn{3}{|c|}{ Stock - Hudson Bay } & \multirow[b]{2}{*}{$p<$} \\
\hline & $\mathrm{N}$ & Mean \pm SD & Range & $\mathrm{N}$ & Mean $\pm \mathrm{SD}$ & Range & \\
\hline WBC & 13 & $5.72 \pm 2.56$ & $3.0-11.4$ & 16 & $13.08 \pm 4.1$ & $7.8-25.7$ & 0.001 \\
\hline $\mathrm{Na}$ & 20 & $160.0 \pm 6.5$ & $147-180$ & 17 & $165.5 \pm 7.4$ & $153-182$ & 0.01 \\
\hline $\mathrm{Fe}$ & 15 & $60.1 \pm 73.2$ & $1-265$ & 14 & $125.7 \pm 46.1$ & $36-193$ & 0.05 \\
\hline Glucose & 20 & $6.56 \pm 0.95$ & $5.2-8.8$ & 17 & $5.72 \pm 1.05$ & $4.2-7.9$ & 0.05 \\
\hline Urea & 20 & $16.8 \pm 2.8$ & $12.1-21.9$ & 17 & $19.7 \pm 3.0$ & $13.1-25.4$ & 0.01 \\
\hline Cholesterol & 20 & $5.89 \pm 1.19$ & $3.5-7.9$ & 14 & $4.32 \pm 1.59$ & $2.7-8.7$ & 0.05 \\
\hline Protein & 20 & $72.4 \pm 5.3$ & $62-83$ & 17 & $84.0 \pm 8.0$ & $69-97$ & 0.001 \\
\hline Globulin & 20 & $32.7 \pm 4.1$ & $23-44$ & 12 & $42.5 \pm 6.9$ & $31-57$ & 0.001 \\
\hline $\mathrm{AG}$ & 17 & $1.3 \pm 0.2$ & $0.9-1.7$ & 12 & $1.0 \pm 0.2$ & $0.7-1.5$ & 0.001 \\
\hline $\mathrm{LDH}$ & 15 & $175 \pm 36$ & $125-237$ & 14 & $290 \pm 118$ & $154-542$ & 0.00 \\
\hline
\end{tabular}

no difference. Conversely, the stock-related differences in $\mathrm{K}$, the $\mathrm{Na}: \mathrm{K}$ ratio, and Ca noted in males were not apparent in females. Mg levels differed between Arctic and Beaufort Sea males, but could not be compared statistically for females from the same areas.

High Arctic mature-sized belugas of both sexes sampled in estuaries during the summer had significantly lower $\mathrm{Na}$ and $\mathrm{K}$ than whales from the same stock in marine waters during the fall migration (Table 8). Within the western Hudson Bay group, significant year-to-year differences were observed in a number of electrolytes and elements. Mean values for $\mathrm{Na}$ ranged from $158.9 \mathrm{mmol} / \mathrm{L}$ in 1987 to $172.8 \mathrm{mmol} / \mathrm{L}$ in $1990 ; \mathrm{Cl}$ values, from $111.3 \pm$ $3.4 \mathrm{mmol} / \mathrm{L}$ in 1988 to $117.1 \pm 3.2 \mathrm{mmol} / \mathrm{L}$ in $1992 ; \mathrm{Ca}$ values, from $2.38 \pm 0.24 \mathrm{mmol} / \mathrm{L}$ in 1987 to $3.13 \pm 0.18$ $\mathrm{mmol} / \mathrm{L}$ in 1988 ; $\mathrm{P}$ values, from $2.31 \pm 0.36 \mathrm{mmol} / \mathrm{L}$ in 1993 to $2.84 \pm 0.30 \mathrm{mmol} / \mathrm{L}$ in 1985 ; and $\mathrm{Fe}$ values, from $45 \pm 12.2 \mu \mathrm{mol} / \mathrm{L}$ in 1985 to $119.1 \pm 30.1 \mu \mathrm{mol} / \mathrm{L}$ in 1987 .

\section{Metabolites}

There were no significant age-associated effects on levels of glucose, urea, creatinine, uric acid, cholesterol, or triglycerides, although the latter three could be statistically compared only in females. Sex-associated differences were noted for urea (Table 5), but only in mature whales from the Arctic stock and not in either mature or immature animals from the Hudson Bay stock. Bilirubin (free, conjugated and total), cholesterol, and triglycerides were not significantly different between the sexes in mature Arctic whales, the only group in which statistical comparisons were possible.

Seasonal differences in several constituents were noted in mature High Arctic whales. Levels of uric acid and triglycerides were higher, and creatinine and bilirubin (free, conjugated and total) were lower, in belugas on their fall migration than during the summer when they were in estuaries (Table 8).

Interannual differences in glucose were evident among western Hudson Bay samples, with yearly means ranging from $5.5 \pm 0.7 \mathrm{mmol} / \mathrm{L}$ in 1993 to $7.1 \pm 0.7 \mathrm{mmol} / \mathrm{L}$ in 1989. Uric acid concentrations ranged from undetectable in six animals in 1989 to a mean of $26.1 \pm 2.6 \mu \mathrm{mol} / \mathrm{L}$ ( $\mathrm{n}=$
20) in 1988; creatinine, from an average of $224 \pm 32.9$ $\mu \mathrm{mol} / \mathrm{L}$ in 1992 to $292 \pm 67.7 \mu \mathrm{mol} / \mathrm{L}$ in 1988 ; cholesterol, from $3.1 \pm 0.8 \mathrm{mmol} / \mathrm{L}$ in 1985 to $6.5 \pm 1.5 \mathrm{mmol} / \mathrm{L}$ in 1992; and triglycerides, from $1.12 \pm 0.28 \mathrm{mmol} / \mathrm{L}$ in 1990 to $2.61 \pm 0.64 \mathrm{mmol} / \mathrm{L}$ in 1992 .

\section{Enzymes}

Alkaline phosphatase (AP) showed no age-, sex-, or stock-related differences in any of the subgroups tested statistically. However, in the full data set, AP activity was significantly higher in immature whales than in mature whales (Table 4). Among mature whales in the Arctic stock, values were significantly higher in animals captured in fall compared to summer (Table 8). Interannual variation in AP was broad in western Hudson Bay, from a mean of 91 $\pm 63 \mathrm{IU} / \mathrm{L}$ in 1993 to one of $472 \pm 184 \mathrm{IU} / \mathrm{L}$ in 1990 .

Immature whales of both sexes had significantly higher levels of creatine phosphokinase (CPK) than did mature whales (Table 4). There were no other significant differences related to sex or stock. Annual means in the western Hudson Bay sample ranged from $99 \pm 43$ IU/L in 1993 to $227 \pm 78$ IU/L in 1987.

Gamma glutamyl transpeptidase (GGT) was higher in males than in females, but only among mature whales in the Hudson Bay stock (Table 5). Levels of GGT in the western Hudson Bay sample were higher in 1993 (26 \pm 16 IU/L) than for most of the other years (means $<14$ IU/L). No significant differences were apparent in any of the statistical comparisons made for alanine aminotransferase (AlAT) or aspartate aminotransferase (AsAT) by age, sex or stock. In 1987, levels of AlAT were significantly higher $(45 \pm 40 \mathrm{IU} / \mathrm{L})$ in the western Hudson Bay sample than in most other years (means < 8 IU/L). In both 1985 and 1987, outlying values of 153 and 167 IU/L, respectively, contributed to the relatively high means for those years. High maximum values for AsAT were also noted in those years, yielding means of $100 \pm 47 \mathrm{IU} / \mathrm{L}$ for 1985 and $123 \pm 45 \mathrm{IU} /$ $\mathrm{L}$ for 1987 . These were significantly higher than the means for all other years, which were less than $80 \mathrm{IU} / \mathrm{L}$. Levels of lactate dehydrogenase (LDH) were significantly higher in mature females from Hudson Bay than in those from the 
TABLE 7. Stock-related differences in hematological and serum chemical constituents among mature-sized male belugas. Stocks represented by fewer than six individuals were not included in statistical comparisons. See Table 3 for unit of measure for each constituent

\begin{tabular}{|c|c|c|c|c|c|c|c|}
\hline \multirow{2}{*}{$\begin{array}{l}\text { Constituent } \\
\mathrm{RBC}\end{array}$} & \multirow{2}{*}{$\begin{array}{l}\text { Stock } \\
\text { Arctic }\end{array}$} & \multirow{2}{*}{$\frac{\mathrm{N}}{8}$} & \multirow{2}{*}{$\begin{array}{l}\text { Mean } \pm \text { SD } \\
3.17 \pm 1.21\end{array}$} & \multirow{2}{*}{$\begin{array}{c}\text { Range } \\
1.7-5.2\end{array}$} & \multicolumn{3}{|c|}{ Statistical Comparison ${ }^{1}$} \\
\hline & & & & & $* *$ & & \\
\hline & Beaufort & 12 & $4.25 \pm 0.35$ & $3.9-5.2$ & $* *$ & & \\
\hline & Hudson Bay & 8 & $3.47 \pm 0.23$ & $3.0-3.67$ & & & \\
\hline \multirow[t]{2}{*}{ Hemoglobin } & Beaufort & 11 & $192 \pm 13.5$ & $165-200$ & $*$ & & \\
\hline & Hudson Bay & 8 & $214 \pm 16.8$ & $180-230$ & * & & \\
\hline \multirow{2}{*}{$\mathrm{MCH}$} & Beaufort & 11 & $45.8 \pm 4.8$ & $34-51$ & $* * *$ & & \\
\hline & Hudson Bay & 8 & $61.6 \pm 1.3$ & $60-64$ & $* * *$ & & \\
\hline \multirow[t]{2}{*}{$\mathrm{MCHC}$} & Beaufort & 11 & $307 \pm 34.5$ & $229-342$ & $* * *$ & & \\
\hline & Hudson Bay & 8 & $369 \pm 12.2$ & $346-383$ & $* * *$ & & \\
\hline \multirow[t]{3}{*}{ WBC } & Arctic & 10 & $5.92 \pm 1.49$ & $4.1-8.8$ & $* * *$ & & * \\
\hline & Beaufort & 12 & $4.05 \pm 1.74$ & $1.8-8.0$ & & $* * *$ & $*$ \\
\hline & Hudson Bay & 8 & $10.79 \pm 3.17$ & $5.7-17.1$ & $* * *$ & $* * *$ & \\
\hline \multirow[t]{3}{*}{$\mathrm{Na}$} & Arctic & 13 & $156.9 \pm 7.3$ & $135-166$ & $*$ & & \\
\hline & Beaufort & 12 & $157.2 \pm 7.1$ & $136-162$ & & $*$ & \\
\hline & Hudson Bay & 8 & $167.4 \pm 8.7$ & $157-182$ & $*$ & $*$ & \\
\hline \multirow[t]{3}{*}{$\mathrm{K}$} & Arctic & 13 & $4.2 \pm 0.8$ & $3.0-5.6$ & $* * *$ & $*$ & \\
\hline & Beaufort & 12 & $3.4 \pm 0.5$ & $2.5-4.2$ & & $*$ & $* * *$ \\
\hline & Hudson Bay & 8 & $5.5 \pm 0.8$ & $4.5-6.6$ & $* * *$ & & $* * *$ \\
\hline \multirow[t]{3}{*}{$\mathrm{Na}: \mathrm{K}$} & Arctic & 13 & $38.4 \pm 6.1$ & $29.7-48.4$ & $*$ & $* *$ & \\
\hline & Beaufort & 12 & $47.0 \pm 8.1$ & $38.6-62.3$ & & $* *$ & $* * *$ \\
\hline & Hudson Bay & 8 & $31.0 \pm 3.3$ & $26.3-35.1$ & $*$ & & $* * *$ \\
\hline \multirow[t]{3}{*}{$\mathrm{Ca}$} & Arctic & 13 & $2.6 \pm 0.20$ & $2.1-2.9$ & & & \\
\hline & Beaufort & 12 & $2.5 \pm 0.11$ & $2.3-2.7$ & $*$ & & \\
\hline & Hudson Bay & 8 & $2.8 \pm 0.18$ & $2.5-3.0$ & $*$ & & \\
\hline \multirow[t]{2}{*}{$\mathrm{Mg}$} & Arctic & 9 & $0.94 \pm 0.08$ & $0.84-1.10$ & $* * *$ & & \\
\hline & Beaufort & 13 & $0.73 \pm 0.09$ & $0.57-0.87$ & $* * *$ & & \\
\hline \multirow[t]{3}{*}{ Urea } & Arctic & 13 & $18.7 \pm 2.2$ & $14.9-22.3$ & $*$ & & \\
\hline & Beaufort & 12 & $14.9 \pm 4.7$ & $1.7-20.1$ & $*$ & $*$ & \\
\hline & Hudson Bay & 8 & $20.3 \pm 2.1$ & $17.8-24.3$ & & $*$ & \\
\hline \multirow[t]{3}{*}{ Creatinine } & Arctic & 13 & $220 \pm 66$ & $123-313$ & $* * *$ & & \\
\hline & Beaufort & 12 & $332 \pm 66$ & $260-501$ & $* * *$ & & \\
\hline & Hudson Bay & 6 & $262 \pm 36$ & $224-314$ & & & \\
\hline \multirow[t]{3}{*}{ Protein } & Arctic & 13 & $73.3 \pm 9.2$ & $54-86$ & $* *$ & & \\
\hline & Beaufort & 12 & $75.6 \pm 4.7$ & $68-82$ & & & \\
\hline & Hudson Bay & 8 & $85.9 \pm 6.3$ & $80-97$ & $* *$ & & \\
\hline \multirow[t]{3}{*}{ Globulin } & Arctic & 13 & $33.0 \pm 4.4$ & $25-37$ & $*$ & $*$ & \\
\hline & Beaufort & 12 & $38.5 \pm 4.1$ & $34-45$ & $*$ & & \\
\hline & Hudson Bay & 8 & $42.2 \pm 6.2$ & $36-54$ & & $*$ & \\
\hline \multirow[t]{3}{*}{$\mathrm{AG}$} & Arctic & 13 & $1.21 \pm 0.10$ & $1.05-1.41$ & $* * *$ & $*$ & \\
\hline & Beaufort & 12 & $0.95 \pm 0.10$ & $0.78-1.10$ & $* * *$ & & \\
\hline & Hudson Bay & 8 & $1.06 \pm 0.18$ & $0.8-1.30$ & & $*$ & \\
\hline \multirow[t]{2}{*}{ T4 (summer only) } & Beaufort & 11 & $168.6 \pm 21.9$ & $135.1-187.9$ & $* *$ & & \\
\hline & Hudson Bay & 13 & $234.2 \pm 64.2$ & $140.3-360.4$ & $* *$ & & \\
\hline
\end{tabular}

${ }^{1}$ Pairs of means identified by asterisks in the same column are significantly different from each other at $p<0.05(*), 0.01(* *)$, or 0.001 $(* * *)$.

Arctic stock (Table 6). Interannual variation in $\mathrm{LDH}$ activity in Hudson Bay whales was large, from $190 \pm 67$ IU/L in 1992 to $362 \pm 110 \mathrm{IU} / \mathrm{L}$ in 1987.

\section{Protein}

Total protein concentrations showed no age-related differences within the Hudson Bay group, but immature whales had significantly higher levels than mature whales in the entire sample (Table 4). Albumin values in Hudson Bay whales were higher in younger females than in older animals of the same sex, but this was not the case for younger males (Table 4). Sex alone had no effect on any of the measures of plasma protein, although sufficient data to examine such effects on protein fractions were available only for immature whales from Hudson Bay. Globulin concentrations were lowest in both males and females from the Arctic stock and highest in those from Hudson Bay, and they resulted in higher AG ratios in this group (Tables 6 and 7). Protein electrophoresis was not performed on a large enough subset of mature whales from the various stocks to examine regional differences. Year-toyear differences in total protein in the western Hudson Bay sample were significant between 1985 and 1988 (82.4 \pm $5.6 \mathrm{~g} / \mathrm{L}$ vs. $90.0 \pm 6.9 \mathrm{~g} / \mathrm{L}$ ). Among the protein fractions, the largest variation was noted in gamma globulin between the 1992 and 1988 samples $(16.3 \pm 4.6$ vs. $45.2 \pm 7.7 \mathrm{~g} / \mathrm{L})$.

\section{Hormones}

Statistical comparisons examining effects of age, sex, and stock on levels of thyroid hormones used only data 
TABLE 8. Hematological and plasma chemical constituents showing seasonal differences in mature-sized beluga whales from the High Arctic stock. See Table 3 for unit of measure for each constituent.

\begin{tabular}{|c|c|c|c|c|c|c|c|}
\hline \multirow[b]{2}{*}{ Constituent } & \multicolumn{3}{|c|}{ Summer Season } & \multicolumn{3}{|c|}{ Fall Season } & \multirow[b]{2}{*}{$p<$} \\
\hline & $\mathrm{N}$ & Mean \pm SD & Range & $\mathrm{N}$ & Mean \pm SD & Range & \\
\hline $\mathrm{RBC}$ & 9 & $2.14 \pm 0.26$ & $1.7-2.5$ & 8 & $3.99 \pm 0.84$ & $2.64-5.2$ & 0.05 \\
\hline $\mathrm{Na}$ & 21 & $156.7 \pm 6.3$ & $135-165$ & 13 & $162.0 \pm 6.5$ & $156-180$ & 0.05 \\
\hline $\mathrm{K}$ & 21 & $4.0 \pm 0.5$ & $3-4.8$ & 13 & $4.6 \pm 1.0$ & $3.5-6.5$ & 0.05 \\
\hline Uric acid & 16 & $11.6 \pm 6.2$ & $5-25$ & 7 & $48.4 \pm 20.6$ & $26-74$ & 0.001 \\
\hline Creatinine & 21 & $251.0 \pm 46.2$ & $174-313$ & 13 & $190.5 \pm 58.3$ & $123-345$ & 0.01 \\
\hline Total bilirubin & 18 & $5.7 \pm 2.4$ & $2.1-9.6$ & 13 & $2.7 \pm 2.6$ & $0-8.0$ & 0.01 \\
\hline Free bilirubin & 18 & $3.4 \pm 2.1$ & $0.2-7.6$ & 13 & $1.8 \pm 1.7$ & $0-4.6$ & 0.05 \\
\hline Conj. Bilirubin & 18 & $2.2 \pm 1.2$ & $0-4.4$ & 13 & $0.9 \pm 1.7$ & $0-6.2$ & 0.05 \\
\hline Triglycerides & 18 & $1.07 \pm 0.51$ & $0.51-2.1$ & 7 & $2.18 \pm 1.32$ & $0.79-5.03$ & 0.01 \\
\hline $\mathrm{AP}$ & 21 & $92 \pm 49$ & $42-234$ & 13 & $227 \pm 81$ & $117-344$ & 0.001 \\
\hline
\end{tabular}

collected during the summer period of estuarine occupation, in recognition of the significant seasonal dynamics of these hormones in belugas (St. Aubin and Geraci, 1989a). In the Hudson Bay stock, immature females, but not males, had higher levels of thyroxine (T4) than did older animals of the same sex (Table 4). Among immatures, females had significantly higher concentrations than did males, whereas the pattern was reversed among the mature whales (Table 5). Mature males in Hudson Bay had greater levels of T4 than their counterparts in the Beaufort Sea, the only other area with sufficient data to allow statistical comparisons (Table 7). For triiodothyronine (T3), males but not females in Hudson Bay showed age-related differences (Table 4), in contrast to the findings for T4. No other sex- or stockrelated differences were noted.

Seasonal differences in T4 were examined for males of all ages, since there were no significant age-related effects on T4 concentration in the Hudson Bay stock. Levels of T4 during summer $(205.8 \pm 54.4 \mathrm{nmol} / \mathrm{L}, \mathrm{n}=85)$ were significantly $(p<0.01)$ higher than in the smaller number of spring $(107.2 \pm 32.2 \mathrm{nmol} / \mathrm{L}, \mathrm{n}=8)$ or fall samples (122 \pm $36.9 \mathrm{mmol} / \mathrm{L}, \mathrm{n}=4)$. Data were insufficient for statistical examination of seasonal effects on $\mathrm{T} 3$ in females, even after combining data from both age-classes, or data on free thyroid hormone levels in any grouping of the data.

For rT3, there was no significant effect of age in females, or of sex in immature whales, from Hudson Bay, the only statistical comparisons that the data set would allow. No seasonal pattern was evident, although mean concentrations for summer $(6.25 \pm 2.84 \mathrm{nmol} / \mathrm{L}, \mathrm{n}=80)$ and fall $(7.15 \pm 4.69 \mathrm{nmol} / \mathrm{L}, \mathrm{n}=6)$ were more than double those determined in spring samples $(2.65 \pm 0.91 \mathrm{nmol} / \mathrm{L}, \mathrm{n}=4)$.

Cortisol concentrations showed no age- or sex-related differences. Immature females had higher levels of aldosterone than immature males in Hudson Bay (Table 5). Stock differences could not be tested for either hormone.

\section{Effect of Tagging}

Two adult females were captured, tagged, and released in Cunningham Inlet, Somerset Island, in July 1997, then recaptured 19 and 24 days later in Coningham Bay, Prince of Wales Island, to recover the data loggers. Blood samples taken on these two occasions showed marked and consistent differences in each of the animals. Investigation of hematological parameters was limited to hematocrit and leucocyte differential counts. At the time of first capture, these values fell within the range established in other whales from this age group, sex, location, and season. On recapture, packed red cell volume had decreased in both whales, falling as low as 0.47 in one individual (Fig. 1). Differential WBC counts revealed changes in the distribution of cells, but absolute numbers for cell types could not be calculated because total leucocyte counts were not performed. The percentages of mature (polymorphonuclear $[\mathrm{PMN}]$ ) and immature (band) neutrophils and monocytes increased, while those of eosinophils and lymphocytes declined.

Changes were also evident in a number of plasma chemical constituents. In both whales, Fe levels had decreased to less than $10 \%$ of the original value, AP activity to $40 \%$, and CPK to $40-45 \%$. Na had declined by $8.2-9.8$ $\mathrm{mmol} / \mathrm{L}$, and $\mathrm{K}$ had increased by $0.3-0.4 \mathrm{mmol} / \mathrm{L}$. Constituents that might have been influenced by recent feeding, such as urea, uric acid, cholesterol, triglycerides, and creatinine, showed inconsistent changes between the two whales. Enzymes diagnostic of organ damage (e.g., AsAT, GGT, LDH, and AlAT) either showed no change or decreased slightly.

\section{DISCUSSION}

Live capture of beluga whales has been undertaken for research and exhibit purposes for decades. Such captures have provided a set of blood samples for this investigation, allowing the development of baseline data for a wide range of circulating constituents. Since blood sample collection is often an ancillary objective of these capture efforts, it may in some instances yield a data set that is biased by the specific needs of the field activity and does not necessarily represent a balanced cross-section of the population. For example, captures designed to collect specimens for exhibit select juveniles for ease of handling and greater 
70

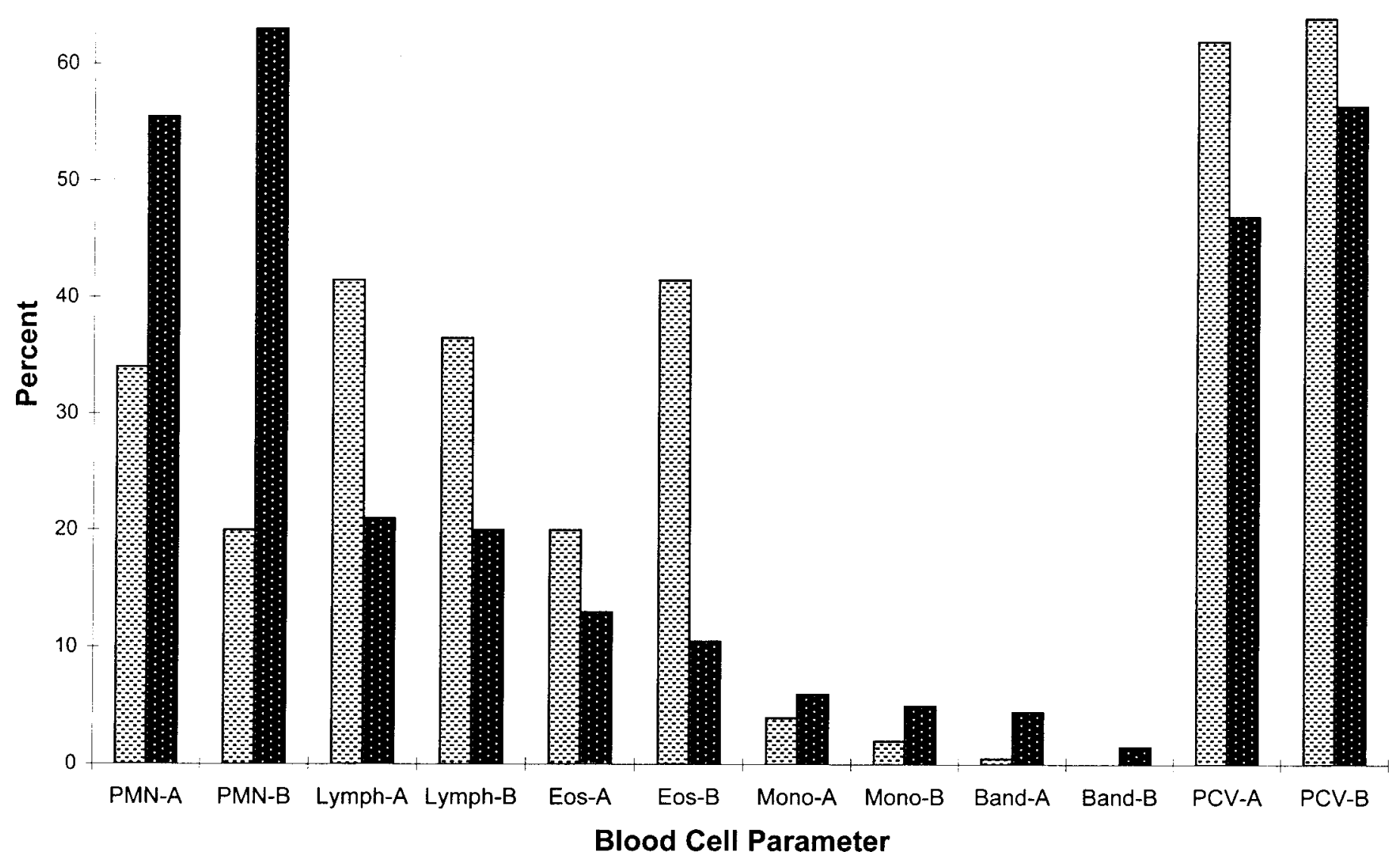

FIG. 1. Changes in leucocyte differential percentage and erythrocyte packed cell volume (PCV) in two beluga whales (A and B) from the time of initial capture (light stippled bars) to recapture (dark stippled bars) after 24 (A) and 19 (B) days.

likelihood of acclimation to captivity. Efforts associated with instrumentation for behavioral studies have tended to select adults, which have a broad dorsal ridge area for instrument attachment, to measure the full expression of diving capability. Thus, certain biases exist according to the year and capture site, depending on the priority of the efforts in each instance. At the same time, this bias in animal selection affords the opportunity to examine the data for specific differences related to important biological and environmental determinants of physiological characteristics. The data presented here reflect that opportunity.

Despite the large number of whales sampled, representation from the 36 possible subgroups defined by age, sex, stock, and season was far from uniform, limiting the options for statistical comparisons designed to elucidate the effects of these variables without the complication of multiple interactions. To maximize the value of the full data set, we combined values from males and females when no sex-related differences were noted, allowing comparisons of immature and mature animals from a larger sample not limited by sex. On occasion, this approach revealed differences that were not apparent when a smaller subset was considered. For example, AP in Hudson Bay whales showed no significant differences by age for each sex or by sex for each age group, and there were no stock-related differences noted within age- and sexspecific groups. However, when all data were included in the analysis, subtle but significant differences in AP activity emerged between immatures and matures, as well as between males and females. Awareness of such tendencies, although expressed in an otherwise heterogeneous group, is nevertheless helpful to those examining plasma chemical data.

As in any long-term study on free-ranging marine mammals, there are a number of impediments to assembling a comprehensive set of data on blood parameters, particularly one that spans 15 years. Laboratory instrumentation is necessarily replaced over such a time interval, and consistency in methodology cannot be maintained. Nevertheless, the use of internal standards in both research and diagnostic laboratories provides a measure of assurance that upgraded equipment or techniques yield results at least comparable to those of the methodology that was being replaced. Greater differences might be expected between the results obtained using the manual hematological techniques sometimes employed in field camps and those obtained using automated instruments. Manual cell counts and hemoglobin determinations, 
particularly, tend to show greater intra-assay variation and are subject to inter-observer error as well.

Age-related differences were examined for evidence of developmental changes in physiology associated with maturation. It should be emphasized that age determinations were made only on the basis of length categories gleaned from size-at-age data for the various regional assemblages of belugas (Doidge, 1990), and it is therefore likely that some individuals may have been incorrectly assigned to immature and mature age groups using these criteria. In the absence of voucher material, principally tooth sections, length is the only objective measure for distinguishing relative age groups. Skin color, which does change with age, can only be assessed subjectively, and this assessment is still flawed in areas such as eastern Hudson Bay, where gray-colored females are apparently old enough to bear calves.

When age- (size-) related differences were apparent, values were almost invariably higher in immature-sized belugas. Leucocyte counts (including total WBC, neutrophils, bands, and lymphocytes), electrolytes (Na and $\mathrm{Ca}$ ), enzymes (AP, CPK, and AlAT), total protein, albumin, globulin, triglycerides, hemoglobin, $\mathrm{MCH}, \mathrm{MCHC}$, T4, and T3 were so affected. Among differences that were statistically significant according to the size categories, only cholesterol, GGT, and Fe were significantly higher in the mature whales. Higher leucocyte indices may reflect the still-developing immune systems of the younger animals, as they mount immunologic responses to a broader range of largely novel antigenic stimuli. Higher protein levels, particularly for globulins, lend some support to this suggestion, but contrast with findings in other species, such as bighorn sheep (Ovis canadensis), in which lower concentrations of immunoglobulins in young animals are thought to reflect a still-developing immune system (Borjesson et al., 2000). Younger, growing animals also characteristically show higher levels of AP and $\mathrm{Ca}$ associated with continued bone development, as noted in other mammals (Kaneko et al., 1997; Borjesson et al., 2000). Other differences have less obvious significance in terms of the physiological needs of immature-sized whales. Within each sex in the Hudson Bay stock, only a few of the agerelated differences were maintained. Immature males had higher T3 and CPK than mature males, and younger females had higher CPK, T4, and albumin, and significantly lower Fe, than mature females. Higher concentrations of thyroid hormones are expected during early development and growth (Haulena et al., 1998).

Sex alone was associated with few differences in the circulating constituents examined. Total RBC counts were greater in males overall. Within the Hudson Bay stock, age influenced the pattern of difference between males and females for T4 concentration: younger females showed higher levels than their male counterparts, whereas older females had lower values than the mature males. The reproductive status of the females may play a role in this shift. Virtually all mature-sized female belugas are pregnant, lactating, or both, and pregnancy has a profound effect on thyroid hormone dynamics (Larsen et al., 1998). The pattern in belugas, however, is reversed from the expected increased levels of circulating $\mathrm{T} 4$, and contrasts with the findings in mature female bottlenose dolphins (St. Aubin et al., 1996). No other difference noted offers particular insight into important physiological differences between male and female belugas.

Interannual variation was examined for animals caught during the summer months in the closely situated estuaries of the Churchill and Seal Rivers. Age, season, and location were comparable, as were the capture methods. The large significant differences noted in numerous constituents were due in part to the fact that sample sizes in some years were small, and mean values were easily skewed by outliers. For example, some individuals had high circulating leucocyte counts indicative of inflammation or elevated hepatic enzymes such as AlAT and AsAT, suggestive of liver damage (Kaneko et al., 1997). Such deviations are readily identified against the background of the larger data set, but demonstrate how a few individuals in less than optimal health might give the misleading impression of a population-wide trend in any given year.

The analysis of blood constituents provided insight into some short-term changes associated with the application of instruments to chart the movements and diving behavior of free-ranging belugas. Two whales that were intentionally recaptured to recover data loggers both showed evidence of leucocytic responses consistent with inflammation and stress. The interval between the onset of the chase and collection of the blood samples was similar in all cases, suggesting that the observed response was associated with tissue damage and repair related to the tag. Gross evidence of necrosis of the epidermis, dermis, and blubber where the attachment pins were inserted can readily account for the observed leucocytic differences. The sharp decrease in $\mathrm{PCV}$, however, is difficult to explain. We can discount blood loss anemia, since no major vessels are found in the area where the transmitters are applied, and there is typically little or no bleeding during attachment of the instruments. Changes in electrolytes are also enigmatic. Higher $\mathrm{Na}$ levels were found in animals captured in the fresh water of Cunningham Inlet than in those from the relatively marine waters of Coningham Bay. Variability in plasma $\mathrm{Na}$ and its relation to environmental salinity are discussed in more detail below. Of the other plasma chemical constituents examined, the sharp decline in Fe levels might be considered as a response to stress and inflammation. No clinically important changes occurred in constituents that are diagnostic of organ damage or failure. The recapture or resighting of other belugas months or perhaps years after they have shed the transmitters (Orr et al., 1998), coupled with the detailed observation of their apparently normal behavior while carrying the instruments, suggests that tagging does not compromise survival. However, our findings in the blood samples demonstrate that the process does appear to challenge the immune system of the whale. 
A singular feature of the beluga's annual cycle is the summertime occupation of estuaries. Environmental conditions in estuaries, principally salinity and temperature, differ dramatically from those of the oceanic waters that belugas inhabit for most of the year. Coupled with extreme seasonal changes in light regime, these conditions might reasonably be expected to influence at least some physiological indicators in these animals. Unique seasonal differences in thyroid hormones have already been described (St. Aubin and Geraci, 1989a) and were maintained in this expanded sample. Elevations in circulating levels of T3 and $\mathrm{T} 4$ are characteristic of summer occupation of estuaries and have been related to growth and molting cycles (St. Aubin et al., 1990). It is also notable that during the period of estuarine occupation, levels of rT3, a metabolically inactive breakdown product of T4, are the highest reported for any mammal. Small sample sizes for spring (4) and fall (6) are inadequate to reveal seasonal shifts in thyroid hormone regulation through the rT3 inactivation pathway. Nevertheless, the changes observed from spring to summer appear to coincide with those of T4; the persistence of high levels of rT3 in the fall, when T4 has declined, might indicate ongoing inactivation of the circulating pool of T4. Further studies on thyroid hormone binding and clearance are needed.

The use of estuaries as gathering sites for molting and socializing exposes belugas for varying periods to an essentially freshwater environment. Low salinity contributes to the loss of superficial skin layers, which become excessively hydrated and are sloughed (St. Aubin et al., 1990). It also presents the animals with an opportunity to drink without having to manage a salt burden. Marine mammals, particularly cetaceans, are presumed to drink very little sea water, meeting most of their needs through preformed and metabolically derived water from their food (Ridgway, 1972). Nevertheless, dolphins, at least, can distinguish the taste of fresh from salt water (Nachtigall, 1986), and might conceivably drink fresh water if presented with the opportunity. Although we have no specific evidence that belugas drink either fresh or salt water, our data show a surprisingly wide range in plasma Na concentrations, which suggests either significant consumption of the water or a physiologically casual approach to regulating water and electrolytes. Values extend well into ranges that would be considered clinically hypo- and hypernatremic in captive belugas (Cornell et al., 1988), with no apparent correlation with the environment in which the animal was sampled. As further evidence of adaptive changes in fluid balance, levels of creatinine, which is excreted by the kidneys, were nearly double those in captive whales, suggesting a reduced renal filtration rate. However, if elevated creatinine levels reflect fluid retention, then it is paradoxical that they should be highest during the summer, when $\mathrm{Na}$ and $\mathrm{K}$ are low, and not during the fall migration, when belugas have reverted to a wholly marine existence. The age-related differences noted in electrolyte concentrations would imply a changing capacity for fluid and electrolyte management with maturation.
One parameter that is subject to considerable adaptive change in mammals is the oxygen-carrying capacity of the blood. The number, size, and hemoglobin content of erythrocytes may vary, depending on activity and environmental conditions that alter the requirement to deliver oxygen to tissues. Ridgway and Johnston (1966), Duffield et al. (1983), and Asper et al. (1990) showed apparent correlations between erythrocytic indices and diving activity within and between species of odontocetes. Belugas have higher hemoglobin and hematocrit than bottlenose dolphins (Asper et al., 1990), killer whales (Orcinus orca) (Cornell, 1983), or harbor porpoises (Koopman et al., 1999), which is consistent with observations on their diving behavior. Studies with captive whales on voluntary dives (Ridgway et al., 1984) and the growing information from instrumented whales (Martin and Smith, 1992, 1999) have demonstrated the profound diving capabilities of belugas, dispelling earlier assumptions that these animals are restricted to shallow, coastal habitat. The wide range of published data on hematocrit in belugas might reflect sampling from different ecotypes, as suggested by Cornell et al. (1988), or adaptive changes within ecotypes (St. Aubin and Geraci, 1989b). We noted no significant differences in hematocrit among the three broad geographical groupings of whales. Erythrocyte counts were highest in Beaufort Sea belugas, but their cell volumes were the lowest among the three groups. The lower mean hemoglobin concentrations in whales from the Beaufort Sea are likely the result of a methodology that did not allow accurate determination of higher concentrations. Thus, there is no evidence from hematological data that belugas from different stocks represent different ecotypes in terms of their ability to exploit deeper waters, nor is there any indication from dive duration data gathered by satellite-linked timed depth recorders that any differences might be expected (Martin and Smith, 1992, 1999).

In all of these determinations, we should consider to what degree the capture event might influence circulating levels of the various blood constituents. Some of these, including leucocytes, adrenal and thyroid hormones, electrolytes, enzymes, and metabolites, were monitored during the post-capture period to establish the time required to recovery of what were presumed to be baseline values (St. Aubin and Geraci, 1989b). In general, the relatively brief duration of chase and the prompt collection of blood samples were considered sufficient to ensure that the constituents under consideration here were affected only minimally. Thyroid hormones are known to decline, but only after 4-6 hours (St. Aubin and Geraci, 1988, 1992). Cortisol and aldosterone may increase, but only after $30 \mathrm{~min}$ (St. Aubin and Geraci, 1990). The relatively longer approach and different capture technique employed for the whales in the Beaufort Sea (Orr et al., 2001) could account for the significantly higher levels of aldosterone, cortisol and, consequently, glucose in this group. Glucose levels in belugas at exhibit facilities, where they are typically trained to provide blood samples without restraint, are more in 
line with the lower values noted in whales captured individually using a hoop net and promptly sampled. Other consequences of glucocorticoid release, such as neutrophilia, lymphopenia, and eosinopenia (stress leucogram), could have developed by the time the blood samples were collected. Elevations in aldosterone are a consistent feature of the stress response in cetaceans (Thomson and Geraci, 1986; St. Aubin et al., 1996) and have been elicited in beluga whales given injections of adrenocorticotropic hormone (ACTH) (St. Aubin and Geraci, 1990).

Muscular activity associated with the chase might be expected to elevate levels of the enzyme CPK (Spraker, 1982), and perhaps the higher activity of this enzyme in the plasma of immatures reflects a more intense struggle on their part to avoid capture. However, there was no impression that the young animals exerted themselves more than the mature whales. Still, mean levels overall were lower than those reported for exhibit animals, although these latter data appear to be skewed by a few elevated values (Cornell et al., 1988). The few samples obtained from belugas killed by Inuit hunters showed no appreciable differences from those obtained from live-captured individuals. The hunted and live-caught animals were usually subjected to a chase of comparable duration. On balance, the data reported here serve as an appropriate baseline for future comparisons using samples that are likely to be collected in a similar fashion.

An additional variable affecting levels of certain plasma constituents stems from the likelihood that at least some of the animals had been feeding prior to capture and sampling. Levels of glucose, triglycerides, and eventually cholesterol will increase sequentially in blood following a meal. Urea will also increase, particularly when the diet is rich in protein. It was not possible to control for whether animals had recently fed or not, or to determine what stage of absorption they had reached. It should be recognized that some of the higher values that we report for these constituents could be the result of dietary factors.

This paper provides one of the largest sets of hematological and plasma chemical analyses for a free-ranging odontocete. Some differences were noted relative to biological factors, such as age and sex of the individual, and environmental factors, such as season and location of sample location. No attempt has been made to identify all of the variables that might have influenced circulating levels of the constituents that we examined. Nevertheless, these data illustrate the variability that might be encountered in an opportunistically selected group of beluga whales, and they serve as a baseline for continued efforts to monitor the health of individuals and populations of beluga whales.

\section{ACKNOWLEDGEMENTS}

We thank the considerable number of individuals, too numerous to name, who were involved in the live-capture efforts that yielded the samples for this analysis. John Hickes and Jack Batstone directed captures in the Churchill and Seal Rivers, and Jack Orr directed those in the Mackenzie River and the High Arctic. We are grateful to Sea World, the Vancouver Aquarium, and the John G. Shedd Aquarium for access to belugas restrained during the process of selecting specimens for exhibit, and to the Inuvialuit and North Baffin hunters and their organizations for their assistance. The clinical diagnostic laboratories at the Churchill Health Center, the Department of Pathology, University of Guelph, and the Faculté de Médecine Vétérinaire, Université de Montréal, provided much more than routine service in the analysis of the samples. Valuable technical support was also provided by K. (Nulick) DeSimone, A. Tucker, C. Stamm, and K. Hunter at Mystic Aquarium. T. Meinert offered advice on the statistical analyses. We thank M.P. HeideJørgensen (Greenland Institute of Natural Resources) and R. Deitz (National Environmental Research Institute, Denmark) for accommodating us as part of their research programs; P. Jess, Jessco Operations, for logistic support on Somerset Island; and the Polar Continental Shelf Project bases at Resolute and Tuktoyaktuk for their steadfast assistance. Funding has been obtained variously from the National Fish and Wildlife Foundation (DJS), the World Wildlife Fund (Canada -JRG, DJS; United States - SD), the Office of Naval Research (DJS), the Canadian Department of Fisheries and Oceans (JRG, DJS, SD), the Nunavut Wildlife Management Board (PR), the Fisheries Joint Management Committee (PR), the U.S. Environmental Protection Agency (SD), the Canadian Wildlife Toxicology Fund (SD), Environment Canada (SD), the Biodôme de Montréal (SD), and the Corporation professionnelle des médecins vétérinaires du Québec ( $\mathrm{SD}$ ). SD received support through fellowships from the Medical Research Council of Canada. This is contribution number 119 from the Sea Research Foundation.

\section{REFERENCES}

ASPER, E.D., CORNELL, L.H., DUFFIELD, D.A., ODELL, D.K., JOSEPH, B.E., STARK, B.I., and PERRY, C.A.. 1990. Hematology and serum chemistry values in bottlenose dolphins. In: Leatherwood, S., and Reeves, R.R., eds. The bottlenose dolphin. San Diego, California: Academic Press. 479-485.

BELTRAN, J.F., RECIO, M., and AZA, C. 1991. Hematological and serum chemical characteristics of the Iberian lynx (Lynx pardina) in south-western Spain. Canadian Journal of Zoology 69:840-846.

BORJESSON, D.L., CHRISTOPHER, M.M., and BOYCE, W.M. 2000. Biochemical and hematologic reference intervals for freeranging desert bighorn sheep. Journal of Wildlife Diseases 36:294-300.

CORNELL, L.H. 1983. Hematology and clinical chemistry values in the killer whale, Orcinus orca. Journal of Wildlife Diseases 19:259-264.

CORNELL, L.H., DUFFIELD, D.A., JOSEPH, B.E., and STARK, B. 1988. Hematology and serum chemistry values in the beluga (Delphinapterus leucas). Journal of Wildlife Diseases 24: 220-224.

DOIDGE, D.W. 1990. Age-length and length-weight comparisons in the beluga whale, Delphinapterus leucas. In: Smith, T.G., St. Aubin, D.J., and Geraci, J.R., eds. Advances in research on the 
beluga whale, Delphinapterus leucas. Canadian Bulletin of Fisheries and Aquatic Science 224. 59-68.

DUFFIELD. D.A., RIDGWAY, S.H., and CORNELL, L.H. 1983. Hematology distinguishes coastal and offshore forms of dolphins (Tursiops). Canadian Journal of Zoology 61:930-933.

DUNBAR, M.R., NOL, P., and LINDA, S.B. 1997. Hematologic and serum biochemical reference intervals for Florida panthers. Journal of Wildlife Diseases 33:783-789.

HANSEN, L.J., and WELLS, R.S. 1995. Bottlenose dolphin health and environmental risk assessment. Eleventh Biennial Conference, Society for Marine Mammalogy, Orlando, Florida. Abstract.

- 1996. Bottlenose dolphin health assessment: Field report on sampling near Beaufort, North Carolina, during July, 1995. NOAA Technical Memorandum NMFS-SEFSC-382. 24 p.

HAULENA, M., ST. AUBIN, D.J., and DUIGNAN, P.J. 1998. Thyroid hormone dynamics during the nursing period in harbour seals, Phoca vitulina. Canadian Journal of Zoology 76:48-55.

HENDRICK, M.S., and DUFFIELD, D.A. 1991. Haematological and rheological characteristics of blood in seven marine mammal species: Physiological implications for diving behaviour. Journal of Zoology, London 225:273-283.

IWC (INTERNATIONAL WHALING COMMISSION). 2000. Annex I. Report of the Sub-committee on Small Cetaceans. Journal of Cetacean Research and Management 2 (Supplement):235-263.

KANEKO, J.J., HARVEY, J.W., and BRUSS, M.L. 1997. Clinical biochemistry of domestic animals. 5th ed. San Diego, California: Academic Press. 932 p.

KOOPMAN, H.N., WESTGATE, A.J., READ, A.J., and GASKIN, D.E. 1995. Blood chemistry of wild harbor porpoises Phocoena phocoena (L.). Marine Mammal Science 11:123-135.

KOOPMAN, H.N., WESTGATE, A.J., and READ, A.J. 1999. Hematology values of wild harbor porpoises (Phocoena phocoena) from the Bay of Fundy, Canada. Marine Mammal Science 15:52-64.

LARSEN, P.R., DAVIES, T.F., and HAY, I.D. 1998. The thyroid gland. In: Wilson, J.D., Foster, D.W., Kronenberg, H.M., and Larsen, P.R., eds. Williams textbook of endocrinology. 9th ed. Philadelphia, Pennsylvania: W.B. Saunders Co. 389-516.

MacNEILL, A.C. 1975. Blood values for some captive cetaceans. Canadian Veterinary Journal 16:187-193.

MARTIN, A.R., and SMITH, T.G. 1992. Deep diving in wild, freeranging beluga whales, Delphinapterus leucas. Canadian Journal of Fisheries and Aquatic Sciences 49:462-466.

- 1999. Strategy and capability of wild belugas, Delphinapterus leucas, during deep, benthic diving. Canadian Journal of Zoology 77:1783-1793.

MEDWAY, W., and MOLDOVAN, F. 1966. Blood studies on the North Atlantic pilot (pothead) whale, Globicephala melaena (Traill, 1809). Physiological Zoology 39:110-116.

NACHTIGALL, P.E. 1986. Vision, audition, and chemoreception in dolphins and other marine mammals. In: Schusterman, R.J., Thomas, J.A., and Wood, F.G., eds. Dolphin cognition and behavior: A comparative approach. Hillsdale, New Jersey: Lawrence Erlbaum Associates. 79-113.
NIELSEN, E., and ANDERSEN, S.H. 1982. Clinical chemistry and hematologic findings in the harbour porpoise (Phocoena phocoena) from Danish waters. Aquatic Mammals 9:1-3.

ORR, J.R., ST. AUBIN, D.J., RICHARD, P.R., and HEIDEJORGENSEN, M.P. 1998. Recapture of belugas, Delphinapterus leucas, tagged in the Canadian Arctic. Marine Mammal Science 14:829-834.

ORR, J.R., JOE, R., and EVIC, D. 2001. Capturing and handling of white whales (Delphinapterus leucas) in the Canadian Arctic for instrumentation and release. Arctic 54(3):299-304.

RICHARD, P.R., MARTIN, A.R., and ORR, J.R. 2001a. Summer and autumn movements of belugas of the eastern Beaufort Sea stock. Arctic 54(3):223-236.

RICHARD, P.R., HEIDE-JØRGENSEN, M.P., ORR, J.R., DIETZ, R., and SMITH, T.G. 2001b. Summer and autumn movements and habitat use by belugas in the Canadian High Arctic and adjacent waters. Arctic 54(3):207-222.

RIDGWAY, S.H. 1972. Homeostasis in the aquatic environment. In: Ridgway, S.H., ed. Mammals of the sea: Biology and medicine. Springfield, Illinois: Thomas. 590-747.

RIDGWAY, S.H., and JOHNSTON, D.G. 1966. Blood oxygen and ecology of porpoises of three genera. Science 151:456-458.

RIDGWAY, S.H., SIMPSON, J.G., PATTON, G.S., and GILMARTIN, W.G. 1970. Hematologic findings in certain small cetaceans. Journal of the American Veterinary Medical Association 157:566-575.

RIDGWAY, S.H., BOWERS, C.A., MILLER, D., SCHULTZ, M.L., JACOBS, C.A., and DOOLEY, C.A. 1984. Diving and blood oxygen in the white whale. Canadian Journal of Zoology 62:2349-2351.

ST. AUBIN, D.J., and GERACI, J.R. 1986. Adrenocortical function in pinniped hyponatremia. Marine Mammal Science 2:243-250.

. 1988. Capture and handling stress suppresses circulating levels of thyroxine and triiodothyronine in beluga whales, Delphinapterus leucas. Physiological Zoology 61:170-175.

- 1989a. Seasonal variation in thyroid morphology and secretion in the white whale, Delphinapterus leucas. Canadian Journal of Zoology 67:263-267.

- 1989b. Adaptive changes in hematologic and plasma chemical constituents in captive beluga whales, Delphinapterus leucas. Canadian Journal of Fisheries and Aquatic Sciences 46:796-803.

- 1990. Adrenal responsiveness to stimulation by adrenocorticotropic hormone (ACTH) in captive beluga whales, Delphinapterus leucas. In: Smith, T.G., St. Aubin, D.J., and Geraci, J.R., eds. Advances in research on the beluga whale, Delphinapterus leucas. Canadian Bulletin of Fisheries and Aquatic Science 224:149-157.

- 1992. Thyroid hormone balance in beluga whales, Delphinapterus leucas: Dynamics after capture and influence of thyrotropin. Canadian Journal of Veterinary Research 56:1-5.

ST. AUBIN, D.J., SMITH, T.G., and GERACI, J.R. 1990. Seasonal epidermal molt in beluga whales, Delphinapterus leucas. Canadian Journal of Zoology 68:359-367.

ST. AUBIN, D.J., RIDGWAY, S.H., WELLS, R.S., and RHINEHART, H. 1996. Dolphin thyroid and adrenal hormones: Circulating levels in wild and semidomesticated Tursiops 
truncatus, and influence of sex, age, and season. Marine Mammal Science 12:1-13.

SPRAKER, T.R. 1982. An overview of the pathophysiology of capture myopathy and related conditions that occur at the time of capture of wild animals. In: Nielsen, L., Haigh, J.C., and Fowler, M.E., eds. Chemical immobilization of North American wildlife. Milwaukee, Wisconsin: Wisconsin Humane Society. $83-118$.
THOMSON, C.A., and GERACI, J.R. 1986. Cortisol, aldosterone, and leucocytes in the stress response of bottlenose dolphins, Tursiops truncatus. Canadian Journal of Fisheries and Aquatic Sciences 43:1010-1016.

VOGEL, I., VIÉ, J.-C., de THOISY, B., and MOREAU, B. 1999. Hematological and serum chemistry profiles of free-ranging southern two-toed sloths in French Guiana. Journal of Wildlife Diseases 35:531-535. 